\title{
POSSIBILITIES OF ORGANIC PRODUCTION IN VOJVODINA
}

\section{S. Grdović ${ }^{1}$, G. Vitorović ${ }^{2}$, B. Petrujkić ${ }^{1}$, B. Mitrović ${ }^{2}$, J. Nedeljković Trailović ${ }^{1}$}

${ }^{1}$ Department of nutrition and botany, Faculty of veterinary medicine, Belgrade University, Bulevar Oslobođenja 18, Belgrade 11000, Republic of Serbia.

${ }^{2}$ Department of radiology, Faculty of veterinary medicine, Belgrade University, Bulevar Oslobođenja 18, Belgrade 11000, Republic of Serbia.

Corresponding author: cecag@vet.bg.ac.rs

Original scientific paper

Abstract: During the past decade, the general attitude of the human population towards health, nutrition quality and environment has remarkably changed. As a result of the growing demand for organic products, especially organic milk, the livestock organic production has increased. Figures from the Serbian Ministry of agriculture estimate that around 75 percent of Serbia's agricultural land, and some 650,000 hectares, can be used for organic food production within three years. The "rule of $30 \%$ " in organic production means that farm animals kept in organic system must ingest at least 30\% of meal dry matter from pastures, makes forage quality of utmost importance. In order to estimate possibilities of organic production in Fruška Gora region forage botanical as well as chemical composition were analysed. A botanical analysis has confirmed presence of plants with high yield and of high nutritive value. Dominant presence of Dactilys glomerata L. and Poa pratensis L. was revealed in the samples of mixed hay, while the Lucerne hay was predominantly composed only by one leguminous species Medicago sativa L. Chemical analyses of hay samples originating from Fruška Gora has pointed out that level of crude proteins, cellulose, fats, macro and trace elements can completely satisfy requirements of animals in organic farming and therefore can present a solid base for further development of organic dairy farming. Possibilities for further development of organic production are great, and it can be expected that organic production will increase in the future and can become a significant branch of livestock production.

Key words: botanical composition, hay, organic production, Serbia

\section{Introduction}

First organic production in Serbia has started in late 70's. For the last ten years, production and processing of organic products became more popular and 
economically more important. Serbia does not have central database system and is hard to give precise figures about the size of organic production. Also the number of certified agents by the Ministry of Agriculture, that are involved in certifying organic production is much less than the total number of agents that are not certified. According to the official data from the certified agents, organic production is currently conducted on around 1,200 ha. But, according to the unofficial data from the agents that are not certified by the Ministry of Agriculture, organic production in Serbia is currently conducted on much larger area of about 5,000 ha; while additional 9,000 ha of land is still in the period of transition towards organic production. That makes total of organic production on some 14,000 ha or only $0.3 \%$ of the total arable land of 4.2 million Ha that is available in Serbia. The total number of registered organic farmers in Serbia is 218. Organic development in Serbia is export driven. The fruit sector products are mainly exported, while vegetables and cereals are both produced for export and for domestic consumption. The most important organic products are wild or cultivated berries exported as frozen or processed and frozen, salted and dried wild mushrooms, other fruits and vegetables. Vegetable and cereal production is located mainly in the region of Vojvodina, while production of fruits and mushrooms is concentrated in the Central and South Serbia. The "rule of 30\%" in organic production means that farm animals kept in organic system must ingest at least $30 \%$ of meal dry matter from pastures, makes forage quality of utmost importance. Serbia has a potential for growth of this sector, but mainly in rural areas where conventional production is not possible or sources of pollution are not near by. Since the financial subsidies for the organic producers in EU are $600 \mathrm{EUR} /$ ha per seasonal crops and $900 \mathrm{EUR} / \mathrm{ha}$ for multiseasonal crops, Serbian producers of organic crops are having difficulties to compete on the EU market. Figures from the Serbian Ministry of agriculture estimate that around 75 percent of Serbia's agricultural land, and some 650,000 hectares, can be used for organic food production within three years. Organic production in Serbia is regulated by the Ministry of Agriculture, Forestry and Water Management's Department for organic production. The new Law on Organic Production and Organic Products was adopted by the Serbian Parliament in July 2006 ("Official Gazette” No. 62/2006). This Law and Ordinances that were lately adopted are harmonized with EU ordinance 2092/91 and EU Ordinance 834/2007 on organic production and labeling. Council regulations (EC) No 2092/91 and 1804/99 describe in detail the allowed organic livestock management in Europe. Great emphasis is placed on welfare friendly feeding. Principles of organic livestock feeding require that ruminant diets should be based on organic feeds in the form of a balanced ration that provides requirents for high quality products rather than maximizing output.

Organic standards require that forage must comprise at least $60 \%$ of the dietary dry matter intake of the organic dairy cow. Aiming for self-sufficiency, organic farming is characterized as a low external input agro-ecosystem. According to organic production standards, all feed should come from the farm itself, or at 
least should be produced within the region (IFOAM, 2002, 2005; Hass et al. 2007). Fruška Gora is a low mountain in the flatlands of the Pannonian Plain.

The valleys of Fruška Gora are covered with meadows and grain fields spread over its slopes, while its higher parts, above 300 meters, are covered with dense deciduous forests. Geographic conditions, good climate and soil conditions of Fruška Gora region promote an intensive use of pastures and meadows. Vegetation of Fruška Gora is characterised by different types of meadow andpastures which are composed from numerous species. Four types of pastures and meadows can be distinguished: lowland meadows, highland meadows and pastures, swamp meadows and pastures of the river valleys (Butorac, 1991).

Each of the mentioned types, is rich with the most significant species of meadowpasture grasses that are of importance in dairy cow nutrition.

In this paper, botanical and chemical composition of Lucerne and mixed hay samples originating from 8 localities of Fruška Gora region was investigated, as well as its self sufficiency for satisfying requirements for organic milk production.

\section{Materials and Methods}

Hay samples were collected according to procedure $A S-1064$ (1993) from Fruška Gora mountain region in a period from August to September 2009. Eight samples each from mixed and Lucerne hay were analyzed. Hay was properly conserved, all parts of the plant were preserved which has enabled exact botanical analyses.

Plants species were determined by floral determination key (Flora Srbije VIII, 1976; Javorka and Csapody, 1991).

Determined species were sorted into classes according to their nutrient value.

Based on organoleptic properties and chemical composition hay quality was determined, consecutively scored and classified according to Leinkeit (1969).

Content of crude ash, crude protein, crude fat, crude cellulose and nitrogen free extract (NFE) was determined in relation to dry matter.

Sample preparation for analyses was done on a procedure according to AOAC (1990). Determination of basic nutritive components was done according to the following procedures: crude moisture SRPS ISO 6496/2001; crude ash SRPS ISO 5984/2002; crude protein SRPS ISO 5983/2001; crude fat SRPS ISO $6492 / 2001$; and content of crude cellulose according to accredited laboratory method (DM1); while content of (NFE) was determined by calculation. Content of calcium $(\mathrm{Ca})$ and magnesium $(\mathrm{Mg})$ was determined by SRPS ISO 6869/2004 and phosphorous $(\mathrm{P})$ by spectrophotometry. Content of trace elements, copper $(\mathrm{Cu})$, iron $(\mathrm{Fe})$, manganese $(\mathrm{Mn})$ and zinc $(\mathrm{Zn})$ was determined by atomic absorption spectrophotometry according to SRPS ISO 6869/2004. 
In statistical analysis descriptive statistical parameters were used (Xsr and SD).

\section{Results and Discussion}

A botanical analysis has confirmed presence of plants with high yield and of high nutritive value. Dominant presence of Dactilys glomerata L. and Poa pratensis L. was revealed in the samples of mixed hay, while the Lucerne hay was predominantly composed only by one leguminous species Medicago sativa L.

Dactilys glomerata L. hay grown in our region gives average yearly yield of 10 to 15 t/ha and Poa pratensis L. 7-10 t/ha. Lucerne hay in Vojvodina yields yearly 8.2 to $8.4 \mathrm{t} /$ ha (Vučković et al., 2002).

Sustainability of farming system under organic management may be increased by the introduction of Lucerne in crop rotation. Lucerne is a recognized as the most widely adapted agronomic crops, important and the cheapest source of protein rich forages of excellent amino acid composition and high digestibility, which is so valuable in economical animal husbandry. Beside that, this species is important for soil improving, especially as effective source of biological nitrogen fixation and it has important place in crop rotation. It is one of the few cultivated plants that can produce high levels of biomass with minimum inputs. It's a reason why Lucerne, besides an important role in conventional husbandry is getting a great role in sustainable agriculture and organic production (Annicchiarico et al., 2006).

Analyses of chemical composition is shown in Table 1.

Table 1. Chemical composition of hay samples

\begin{tabular}{|l|c|c|}
\hline & Mixed hay (Xsr \pm SD) $\mathrm{n}=8$ & Lucerne hay (Xsr \pm SD) $\mathrm{n}=8$ \\
\hline Moisture (\%DM) & $13.70 \pm 0.4613 .01 \pm 0.57$ & $13.70 \pm 0.4613 .01 \pm 0.57$ \\
\hline Crude ash (\%DM) & $7.69 \pm 0.847 .88 \pm 0.31$ & $7.69 \pm 0.847 .88 \pm 0.31$ \\
\hline Crude protein (\%DM) & $10.13 \pm 0.7016 .32 \pm 0.48$ & $10.13 \pm 0.7016 .32 \pm 0.48$ \\
\hline Crude fat (\%DM) & $1.04 \pm 0.130 .88 \pm 0.08$ & $1.04 \pm 0.130 .88 \pm 0.08$ \\
\hline Crude cellulose (\%DM) & $33.96 \pm 3.7239 .57 \pm 1.01$ & $33.96 \pm 3.7239 .57 \pm 1.01$ \\
\hline NFE (\%DM) & $33.05 \pm 2.2722 .34 \pm 1.08$ & $33.05 \pm 2.2722 .34 \pm 1.08$ \\
\hline Calcium (\%DM) & $1.11 \pm 0.392 .79 \pm 0.19$ & $1.11 \pm 0.392 .79 \pm 0.19$ \\
\hline Phosphorous (\%DM) & $0.38 \pm 0.090 .55 \pm 0.05$ & $0.38 \pm 0.090 .55 \pm 0.05$ \\
\hline Magnesium (\%DM) & $0.21 \pm 0.040 .31 \pm 0.03$ & $0.21 \pm 0.040 .31 \pm 0.03$ \\
\hline Iron $(\mathrm{mg} / \mathrm{kg})$ & $358.4 \pm 81.111279 \pm 175.7$ & $358.4 \pm 81.111279 \pm 175.7$ \\
\hline Zinc $(\mathrm{mg} / \mathrm{kg})$ & $17.63 \pm 1.0018 .08 \pm 1.21$ & $17.63 \pm 1.0018 .08 \pm 1.21$ \\
\hline Manganese (mg/kg) & $43.10 \pm 7.3987 .26 \pm 5.90$ & $43.10 \pm 7.3987 .26 \pm 5.90$ \\
\hline Copper $(\mathrm{mg} / \mathrm{kg})$ & $8.52 \pm 0.788 .63 \pm 0.20$ & $8.52 \pm 0.788 .63 \pm 0.20$ \\
\hline
\end{tabular}

$* \% \mathrm{DM}-$ percentage of dry matter

Chemical analyses of hay samples originating from Fruška Gora has pointed out that level of crude proteins, cellulose, fats, macro and trace elements 
can completely satisfy requirements of animals in organic farming and therefore can present a solid base for further development of organic dairy farming.

Calculated crude protein content of plants grown (according to nitrogen percentage) gives average yield of 861 to $1266 \mathrm{~kg}$ per ha.

Dairy cows with average milk yield of $5.000 \mathrm{~kg}$ milk animal ${ }^{-1} \mathrm{year}^{-1}$ in organic farming, have demands of $115 \mathrm{~kg}$ of crude nitrogen which equals 718.75 $\mathrm{kg}$ of crude protein (Lund, 2003).

Mixed hay samples cultivated on one ha in region of Fruška Gora can therefore provide nutrients for breeding of 1.20 to 1.76 dairy cows, per ha. Bakker and Heerdt (2005) have monitored forage quality on the grasslands in the Netherlands, during the period of 11 years after transition from conventional to organic farming. They have concluded that it remained sufficient for the production of $6000 \mathrm{~kg}$ milk animal ${ }^{-1}$ year $^{-1}$. The vegetation showed considerable changes during the study period. The sandy pastures initially featured a strong dominance of L. perenne, which however declined dramatically from $90 \%$ to $20 \%$ cover during the study period. At the end of the study period six grass species occurred with similar cover percentages, namely, Alopecurus pratensis, Dactylis glomerata, Holcus lanatus, Lolium perenne and Poa trivialis. These findings are in accordance to our findings since we have found that Dactylis glomerata and Poa pratensis were the dominant species. On the other hand Korevaar (1986) found that on extensively, unfertilized grazed grassland due to low nitrogen availability, finds hard to reach the forage quality to feed a cow with a production of $5000 \mathrm{~kg}$ milk animal $^{-1}$ year $^{-1}$ properly. Based on our findings pastures and meadows of Fruška Gora, present a solid base for organic dairy farming.

Measured crude protein content of Lucerne hay was $16.32 \%$ which gives 1338 to $1371 \mathrm{~kg}$ of crude protein per ha of Lucerne hay. This amount of proteins can therefore provide demands of 1.86 to 1.91 dairy cows with milk production of $5.000 \mathrm{~kg}$ milk animal-1 year-1. This result is in compliance with the results of (Marković et al., 2007a; Đukić et al., 2007). The Lucerne hay is characterized by a high content of crude protein, well balanced with respect to amino acids. It is rich in vitamins, and various trace elements essential for normal growth and development of animals (Marković et al., 2007a). Lucerne is the basic component in the feeding program for dairy cattle, as well as for beef cattle, horses, sheep and other classes of livestock. Beside that, rapid recovery after cutting, longevity and tolerance to environmental stress is important for stabile yield during all periods of exploitation. Also, symbiotic $\mathrm{N}_{2}$ fixation in Lucerne eliminates the need for use of chemical $\mathrm{N}$ and adds a beneficial carryover effect in crop rotation.

In Serbia, Lucerne is the second most important forage crop after maize. It is grown on over 200000 ha in pure stand, which is about $4 \%$ of total agricultural area in Serbia (Đukić et al., 2007). Sustainable agriculture and organic production are an important part of research projects and agricultural development in Serbia, and the special role in those productions belongs to Lucerne. Lucerne is regarded as a highly nutritious animal feed and it is preferred to other forages in feeding 
ruminants. The demand arises because its primary nutritive values is based on rapid passage through the gastrointestinal tract, large amounts of soluble protein provided for rumen microorganisms for resyntesis of proteins, synthesis of $\mathrm{B}$ vitamins and stimulation of cellulose digestion, vitamin $\mathrm{A}, \mathrm{E}$ and $\mathrm{K}$ or their precursor contents all of which are vital protective nutrients when Lucerne forages are fed to dairy cattle. Lucerne has relatively large amounts of cell solutes and the lowest amount of cell walls in comparison with other forages (Tomić et al., 2001). The Lucerne hay samples were characterized by higher Ca-contents $(2.79 \pm 0.19)$, compared to mixed hay samples $(1.11 \pm 0.39)$. The contents of $\mathrm{P}$ were, however, similar to those of grasses. These finding are in accordance to the findings of Gruber et al. (1999). Content of trace elements in examined mixed and Lucerne hay samples did not differ significantly. Similar to these were the findings of Marković et al. (2007b).

The practical value of Lucerne is not restricted to its fodder qualities alone. It also performs other important economic and biological functions: it enriches the soil with nitrogen, is a good predecessor for many agricultural crops, serves as a desalinator crop, it's a good green-manure and nectar producing crop and reduces effect of water and wind erosion by binding the soil. Cultivation of Lucerne in crop rotation fields not only improves soil fertility, but also increases the yield of subsequent crops. All this traits make Lucerne essential in organic agriculture (Torricelli, 2006).

\section{Conclusion}

Possibilities for further development of organic production are great, and it can be expected that organic production will increase in the future and can become a significant branch of livestock production.

Organic farming concept is based on use of minimally $60 \%$ of roughage which originates from organically cultivated grasslands in the region of the farm.

Production level of grasslands on Fruška Gora gives the possibility for breeding 1.20 to 1.91 dairy cows per ha of grassland, depending on hay type (mixed or Lucerne hay) and therefore can be a solid base for further development of organic dairy farming.

\section{Acknowledgment}

This work was supported by Grants No III46002 and TR031085 Ministry of Education and Science - Republic of Serbia 


\title{
Mogućnosti organske proizvodnje u Vojvodini
}

\author{
S. Grdović, G. Vitorović, B. Petrujkić, B. Mitrović, J. Nedeljković-Trailović
}

\section{Rezime}

Proteklih decenija opšti stav ljudske populacije prema zdravlju, kvalitetu ishrane i životnoj sredini je promenjen. Kao rezultat rastućih potreba za organskim proizvodima, naročito organskim mlekom, povećala se i organska proizvodnja stoke. Podaci iz srpskog Ministarstva poljoprivrede procenjuju da oko 75 odsto poljoprivrednog zemljišta Srbije, a nekih 650.000 hektara, može se koristiti za proizvodnju organske hrane u roku od tri godine. "Pravilo 30\%" u organskoj proizvodnji znači da životinje na farmama koje se gaje u sistemu organske proizvodnje moraju unositi najmanje $30 \%$ od obroka suve materije sa pašnjaka, čineći da je kvalitet krme najvažniji. U cilju procene mogućnosti organske proizvodnje u regionu Fruške Gore analiziran je botanički i hemijski sastav krme. Analiza botaničkog sastava potvrdila je prisustvo biljaka koje se odlikuju visokim prinosom i velikom nutritivnom vrednošću. Dominantno prisustvo Dactilys glomerata L. i Poa pratensis L. otkriveno je u uzorcima mešovitog sena, dok je lucerkino seno uglavnom bilo sastavljeno iz jedne leguminozne vrste Medicago sativa L. Hemijski sastav uzoraka sena iz Fruške Gore ukazuje da nivo sirovih proteina, celuloze, masti, makro i elemenata u tragovima mogu u potpunosti da zadovolje potrebe životinja na organskim farmama i zbog toga mogu predstavljati solidnu osnovu za dalji razvoj organske proizvodnje mleka. Mogućnosti za dalji razvoj organske proizvodnje su velike i moglo bi se očekivati da će se u budućnosti organska proizvodnja uvećati da će postati značajna grana u stočarskoj proizvodnji.

\section{References}

ANNICCHIARICO P., PECETTI L., DE ROSA L., PIANO E. (2006): Lucerne variety evaluation for organic farming in nothern Italy. Proceedings 26th Eucarpia Fodder Crops and Amenity Grasses Section Meeting, 65-71.

AOAC (Association of Official Analytical Chemists) (1990): Official Methods of Analysis of the Association of Official Analytical Chemists, Thirteenth Edition, Association of Official Analytical Chemists (publisher), Washington, DC 20044, USA, 1018.

AS-1064 (1993): Sampling Feed for Analysis.Verlag Paul Parey, Hamburg, Berlin, $1-52$.

BAKKER J.P., HEERDT TER G.NJ. (2005): Organic grassland farming in the Netherlands: a case study of effects on vegetation dynamics. Basic Appl Ecol., 6, 205-14. 
BUTORAC B. (1991): Neke biljke diferencijalnog karaktera za floru zapadnog dela Fruške gore. Zbornik radova PMF, Univerziteta u Novom Sadu. Serija za biologiju. 21, 5-14 (in Serbian).

ĐUKIĆ D., LUGIĆ Z., VASILJEVIĆ S., RADOVIĆ J., KATIĆ S., STOJANOVIĆ I. (2007): Domaće sorte višegodišnjih leguminoza - nastanak i kvantitativna svojstva. Zbornik radova, Institut za ratarstvo i povrtarstvo, Novi Sad, 44, 1, 7-20. EC (1991): Council Regulation (EEC) No 2092/91 of 24 June 1991 on organic production of agricultural products and indications referring thereto on agricultural products and foodstuffs. Offic. Jour. Europ. Commun. L198 (22.7.91), 1-15.

EC (1999): Council Regulation (EC) No 1804/1999 of 19 July 1999 supplementing Regulation (EEC) No. 2092/91 on organic crop production of agricultural products and indications referring thereto on agricultural products and foodstuffs to include livestock production. Offic. Jour. Europ. Commun. L222 (24.8.1999), 1-28.

FLORA SR SRBIJE VIII (1976): Srpska akademija nauka i umetnosti, Beograd.

GRUBER L., STEINWIDDER A., STEFANON B., STEINER B., STEINWENDER R. (1999): Influence of grassland management in alpine regions and concentrate level on $\mathrm{N}$ excretion and milk yield of dairy cows. Livest Prod Sci., 61, 155-70.

HAAS G., DEITTERT C., KÖPKE U. (2007): Impact of feeding pattern and feed purchase on area - and cow related dairy performance of organic farms. Livestock Sci., 106, 132-44.

IFOAM (International Federation of Organic Agriculture Movements) (2002): Norms for Organic Production and Processing-IFOAM, Basic Standards, IFOAM, Head office, Bonn, Germany.

IFOAM (International Federation of Organic Agriculture Movements) (2005): Norms for Organic Production and Processing-IFOAM, Basic Standards, IFOAM, Head office, Bonn, Germany.

JAVORKA S., CSAPODY V. (1991): Iconographia florae partis austro-orientalis europae centralis. Akademiai Kiado, Budapest.

KOREVAAR H. (1986): Produktie en voedingswaarde van gras bij gebruiks- en bemestingsbeperkingen voor natuurgebieden. Report 101, Proefstation voor de Rundveehouderij, Schapenhouderij en Paardenhouderij, Lelystad.

LEINKEIT W. (Ed.) (1969): Handbuch der Tierernährung, Zweiter Band: Leistungen and Ernährung.

LUND V., ALGERS B. (2003), Research on animal health and welfare in organic farming-a literature review. Livest Prod Sci., 80, 1-2, 55-68.

MARKOVIĆ J., RADOVIĆ J., LUGIĆ Z., SOKOLOVIĆ D. (2007a): The effect of development stage on chemical composition of alfalfa leaf and stem. Biotechnology in Animal Husbandry, 23, 5-6, Book 2, 383-388.

MARKOVIĆ J., IGNJATOVIĆ S., RADOVIĆ J., LUGIĆ Z. (2007b): Uticaj faze razvića na sadržaj makro i mikroelemenata u lucerki i crvenoj detelini. Zbornik radova, Institut za ratarstvo i povrtarstvo, Novi Sad, 44, 1, 401-406. 
Pravilnik o kvalitetu i drugim zahtevima za hranu za životinje (Sl. list SRJ br. 20/00 i 38/01).

TOMIĆ Z., IGNJATOVIĆ S., RADOVIĆ J., SOKOLOVIĆ D. (2001): Lignifikacija celuloze i mineralnih materija u travama, leguminozama i festololium hibridima. Biotechnology Animal Husbandry 17, 5-6, 219-225.

TORRICELLI R. (2006): Evaluation of lucerne varieties for organic agriculture. Proceedings 26th Eucarpia Fodder Crops and Amenity Grasses Section Meeting, 141-144.

VUČKOVIĆ S., SIMIĆ A., JAKOVLJEVIĆ M., PETROVIĆ R., MLADENOVIĆ G., VUČKOVIĆ M. (2002): Forage yield and quality of perennial ryegrass as affected by different rates of nitrogen fertilizer under calcareous soils in northwestern Yugoslavia. Grassland Scince in Europe, 7, 486-487.

Received 30 June 2011; accepted for publication 15 August 2011 